\title{
Family violence, employment status, welfare benefits, and alcohol drinking in the United States: what is the relation?
}

\author{
E Rodriguez, K E Lasch, P Chandra, J Lee
}

Cornell University, Department of Policy Analysis and Management, and Graduate School of Medical Sciences, Medical College and Sloan-Kettering Divisions, USA E Rodriguez

The Health Institute/Division of Clinical Care Research of the New England Medical Center and the Department of Medicine of Tufts University School of Medicine, USA K E Lasch

Cornell Institute for Social and Economic Research, Cornell University, USA P Chandra

The Health Institute/Division of Clinical Care Research of the New England Medical Center, USA

J Lee

Correspondence to: Dr Rodriguez, 140 MVR Hall, Cornell University, Ithaca, NY 14850, USA (er23@Cornell.edu)

Accepted for publication 7 January 2000

\begin{abstract}
Objectives-This study examined the contribution of employment status, welfare benefits, alcohol use, and other individual, and contextual factors to physical aggression during marital conflict.

Methods-Logistic regression models were used to analyse panel data collected in the National Survey of Families and Households in 1987 and 1992. A total of 4780 married or cohabiting persons reinterviewed in 1992 were included in the analysis. Domestic violence was defined as reporting that both partners were physically violent during arguments.

Results-It was found that non-employed respondents are not at greater risk of family violence in comparison with employed respondents, after controlling for alcohol misuse, income, education, age, and other factors; however, employed persons receiving welfare benefits are at significantly higher risk. Alcohol misuse, which remains a predictor of violence even after controlling for other factors, increases the risk of family violence while satisfaction with social support from family and friends decreases it. Conclusion-These results underscore the important effect of alcohol misuse on domestic violence, and the need to monitor the potential impact of welfare reform on domestic violence.
\end{abstract}

(F Epidemiol Community Health 2001;55:172-178)

Family violence has been recognised as a public health problem for almost a decade, ${ }^{1}$ and the health care cost associated with treatment of family violence injuries in the United States has been estimated as high as $\$ 857$ million annually. ${ }^{2}$ In analysis of 1985 National Violence Survey data, Straus and Gelles found an annual incidence of marital aggression of approximately $16 \% .^{3}$ In $1992,12 \%$ of all homicides were the result of intrafamilial violence. ${ }^{4}$ Estimates are that as many as 2 to 4 million women a year are physically battered by their intimate partners. ${ }^{5}$ Men are as likely as women to resort to physical aggression during marital conflicts but women are more likely to report injury from such interchanges. ${ }^{6}$

Family violence has been associated with gender and power issues ${ }^{7-9}$; structural and sociodemographic characteristics such as age, socioeconomic status, unemployment, cohabiting status, and partnership stability ${ }^{10-13}$; alcohol and drug misuse ${ }^{1415}$ and depression. ${ }^{16}{ }^{17}$ The research on family violence has produced results that are difficult to integrate conceptually or empirically. Most of this research has been on small select samples and cross sectional.

The role of alcohol in violence is especially controversial. ${ }^{141819}$ Studies have found that alcohol use may aggravate marital difficulties leading to separation or divorce, ${ }^{17}$ and alcohol problems may have an indirect effect on earnings and marriage. ${ }^{20} 21$ One longitudinal study, however, found that alcohol consumption was significantly related to physical aggression six months immediately before and after marriage, but the effects washed out at 18 months. ${ }^{22}$ Others have suggested that structural factors such as unemployment may disrupt community and social relationships leading to greater risk behaviour such as alcohol consumption. ${ }^{13}$ Unemployment, however, has been inconsistently related to both alcohol intake ${ }^{13}{ }^{23}$ and violent incidents. ${ }^{24}$ Job loss has been found to be related to an increase of negative behaviours between partners, ${ }^{24}$ but again the relation between job loss and violence is not clear cut. While small increases in lay offs are associated with more violent incidents, large increases are associated with reduced incidence. ${ }^{25}$

Employment in itself does not necessarily protect couples from marital violence. Stressful work experiences have also been found to be associated with wife abuse. ${ }^{26}$ In addition, it has been suggested that an increase of female employment and transitions towards different forms of relationships may generate tensions that could increase the likelihood of marital violence. ${ }^{27}$ This is particularly relevant given our fast changing economy and increasing employment demands on young parents, ${ }^{28}{ }^{29}$ including those receiving welfare benefits.

There is evidence that welfare reform accounted for $44 \%$ of the employment rate gain from 1992 to $1996,{ }^{30}{ }^{31}$ and The Personal Responsibility and Work Opportunity Reconciliation Act of 1996 (Public Law 104-193) will force more women with young children to work. In the current policy debate, not only is there little concern with the impact of welfare reform on women's health, ${ }^{32}$ but little thought has been given to a potential for increased domestic violence.

Increasingly social scientists note the importance of taking context into account when explaining outcomes and the necessity of looking at the way in which family, work, and community factors interrelate to explain attitudes and behaviours. ${ }^{33-36}$ Research on violence 
should also consider the impact of social and economic environmental factors. ${ }^{37} 38$

The goal of this study is to contribute to our understanding of the complex and important issue of family violence. Using panel data from the 1987 and 1992 National Survey of Families and Households (NSFH), we attempt to disentangle the effects of employment, partnership instability, and alcohol use in the risk of domestic violence.

Figure 1 summarises our explanatory model. We take advantage of longitudinal data and controlling for individual and household characteristics and prior problems with alcohol misuse, violent arguments, and joblessness (1987 and 1991 variables), we ascertain the influence of current alcohol misuse, and employment status on current violence (1992 variable). Our explanatory model draws from a sociostructural approach, in the sense that violent arguments are seen as arising from changing and increasing demands placed on the family, ${ }^{26} 38$ and from a social learning approach that considers the influence of variables such as occupational status on the onset of violence. ${ }^{26}$ We broaden the employment status variable to include working and receiving welfare.

\section{Methods}

DATA

The 1987 NSFH survey consisted of interviews with 13017 respondents, including an over-sample of minorities and households containing single parent families, stepfamilies, recently married couples, and cohabiting couples. The 1992 survey includes a reinterview of 10008 surviving members of the original sample, which represents an attrition rate of $23 \%$. We analysed possible differences between respondents to the 1992 survey and those who were lost to follow up after the 1987 interview. There were no significant differences in attrition rates by gender, age, ethnic group, and marital status between those who were re-interviewed and those lost to follow up. We limited our study to respondents older than 16 years of age in 1987, and who were not retired in 1992. A total of 4770 married or cohabiting individuals were included in our analyses.

$\begin{array}{ll}\begin{array}{l}\text { Fixed personal } \\ \text { characteristics }\end{array} & \begin{array}{l}\text { Other individual and } \\ \text { household characteristics }\end{array} \\ \text { - } \begin{array}{l}\text { Age } \\ \text { Sex }\end{array} & \text { Education } \\ \text { Race/ethnicity } & \text { Family income } \\ & \text { Number of children }\end{array}$

Figure 1 Explanatory model.
MEASURES

In this study we focus on violent arguments in which both partners participate. About $60 \%$ of respondents who engaged in violent arguments in 1992 reported that both partners used physical violence (151 of 247). Of 247 respondents who reported having violent arguments only 25 reported being the only perpetrator of violence, and 71 said that only the spouse or partner used violence. We considered these two groups to be too small to include in our analysis and excluded them. We explored possible reporting differences between the three variants of family violencethat is, spouse/partner violent, respondent violent, and both mutually violent. In general, those who reported that only the partner used physical violence were, on average, older (mean age 35.4 versus 33.4 years) and more educated (mean of 13.6 versus 12.5 years) than those who also reported being active participants in violent arguments.

As noted in a previous analysis of the NSFH, women were as likely as men to commit violent acts, but women were more likely to report being injured than men. ${ }^{39}$ Here we focus on predictors of violent interchanges not on their possible consequences.

Our dependent variable, family violence, was measured by the question: In the past year, did both respondent and partner become physically violent during an argument? We investigated potential differences between respondents and non-respondents to this question in terms of gender, alcohol drinking patterns, race/ethnicity, and total number of children in the household. The number of nonrespondents was small $(n=171)$ and no significant differences were observed between groups.

We constructed an employment situation variable from several variables that asked about respondents' employment and sources of income in 1992. Respondents were divided into four categories: (a) full time employed, (b) part time employed, (c) working while receiving welfare benefits, and (d) non-employed. Given the few episodes of violence reported by retired people (only 2 of 327 retired respond-

$\begin{array}{ll}\begin{array}{l}\text { Background risk } \\ \text { factors }\end{array} & 1992 \text { risk factors } \\ & \\ \text { Reporting violent } & \\ \text { arguments in } 1987 & \text { Employment status } \\ \text { Reporting having } & \text { Alcohol drinking } \\ \text { problems with alcohol } & \text { Dissatisfaction with } \\ \text { in } 1987 & \text { social relationships } \\ \text { Change of partner } & \\ \text { between } 1987 \text { and } 1992 & \\ \begin{array}{l}\text { Length of time } \\ \text { unemployed and looking } \\ \text { for work in 1991 }\end{array} & \\ \begin{array}{l}\text { Having a mental or } \\ \text { physical condition that } \\ \text { could limit the ability } \\ \text { of working for pay }\end{array}\end{array}$


ents reported violence), this group was not included in our analysis. Of all 1055 nonemployed respondents only 76 were looking for work, and of those only six reported violent arguments, which did not allow us to look at them separately. In addition, 208 nonemployed respondents were receiving some type of social or welfare benefits. Preliminary analysis showed that they were not statistically different from other non-working people, and we kept them together to increase the statistical power of our model.

We used the total number of drinks that the respondent had in the past 30 days as our measure of alcohol drinking in 1992. Covariates we controlled for were the respondent's gender, age, race/ethnicity, partnership stability, years of education, total household income, number of children in the household, satisfaction with friends and family, and having a mental or physical condition that could limit the ability to work for pay. Partnership stability was measured as three different types of partnership: (a) respondents that were in stable relationships (that is, married or living together in 1992 to the same person as in 1987); (b) respondents that have a different partner than the one they had in 1987; and (c) new couples (that is, those who were not married or living together in 1987). Besides taking into consideration partnership stability, we explored whether other partner characteristics such as having had problems with alcohol or drugs could have an impact on predicting family violence. However, very few respondents indicated that their partners or other family members have had problems with drugs or alcohol in 1987, and we were not able to include this variable in our analysis.

Other background factors included in our model were number of weeks unemployed and looking for work in 1991, reporting engaging in violent arguments in 1987, and having alcohol problems in 1987.

\section{STATISTICAL ANALYSIS}

We conducted logistic regression analyses to examine the relations of interest using SAS. ${ }^{40}$ In all our analyses, we weight the survey responses to account for the over-sampling of special populations in the survey, including African American, single parent families, families with step children, cohabiting couples and recently married persons. The weights were prepared by the NSFH researchers. ${ }^{41}$ We used Box-Cox transformation of the income, and alcohol intake variables, a frequently used procedure that smoothes out the effect of outlier values and approximates the variables to a normal distribution. The transformations were sufficient to produce reasonable residual plots (see tables for details on the transformations used). We examined the correlations among all variables, performed diagnostic tests for collinearity, and no problems were found.

We did not replace any missing values of the dependent variable. For the categorical independent variables we added an additional group of "no response or not applicable" where necessary, in order to include all respondents in
KEY POINTS

- Employed persons receiving welfare benefits are at significantly higher risk of domestic violence.

- Non-employed respondents are not at greater risk of family violence relative to employed persons. However, alcohol interacts with non-employment to predict violence.

- In contrast with popular perception race/ ethnicity is not a significant factor in predicting violent arguments when other factors are accounted for.

- Two factors significantly reduce the likelihood of engaging in violent arguments: age and satisfaction with relationships with friends and family (other than the spouse).

our analysis. For the continuous independent variables we replaced missing values by imputing them with the predicted value estimated for the age, gender, ethnic, marital status, and employment situation group of the respondent.

Firstly, we conducted logistic regression in our full model described in figure 1. To have sufficient cell size to examine interaction effects between employment situation and social support, alcohol use, and number of children, we then dropped some of the variables that were non-significant in our first analysis, and created a shorter model. Our reduced model controls for age, sex, income, education, and prior violence (1987), while analysing the impact of current employment status, alcohol drinking, satisfaction with relationships, and number of children in the household. We then ran three separate models with interactions for satisfaction with relationships, alcohol misuse, and number of children.

\section{Results}

Table 1 presents a description of our sample. Of 4780 respondents, 151 report engaging in arguments in which both partners were physically violent toward each other. As shown in table 1 , women were slightly more likely than men to report the occurrence of violent arguments.

The average household income and years of education are lower among those who report violent arguments than among those who do not report them. Respondents who engage in violent arguments have more children, and report more alcohol drinking and weeks of unemployment in 1991 than respondents who do not report violence. The average age of respondents engaging in violent arguments is 33 years (SD 6.7), while the average age of those not resorting to violence is 40 years (SD 10).

Full time employed people are less likely and those working while receiving welfare benefits are more likely to report violence relative to other employment status groups. Working part time and being non-employed does not increase the risk of violence. African American 


\begin{tabular}{|c|c|c|c|c|c|c|}
\hline \multirow[b]{2}{*}{ Characteristics of respondents } & \multicolumn{2}{|l|}{ Complete sample } & \multicolumn{2}{|c|}{ Women respondents } & \multicolumn{2}{|l|}{ Men respondents } \\
\hline & $\begin{array}{l}\text { Violent } \\
\text { arguments: } \\
\text { (both partners) }\end{array}$ & $\begin{array}{l}\text { No violent } \\
\text { arguments }\end{array}$ & $\begin{array}{l}\text { Violent } \\
\text { arguments: } \\
\text { (both partners) }\end{array}$ & $\begin{array}{l}\text { No violent } \\
\text { arguments }\end{array}$ & $\begin{array}{l}\text { Violent } \\
\text { arguments: } \\
\text { (both partners) }\end{array}$ & $\begin{array}{l}\text { No violent } \\
\text { arguments }\end{array}$ \\
\hline Total sample & 151 & 4629 & 90 & 2590 & 61 & 2039 \\
\hline Employment status in 1992 & Number (\%) & Number (\%) & Number (\%) & Number (\%) & Number (\%) & Number (\%) \\
\hline Full time work & $87(57.6)$ & $3061(66.1)$ & $40(44.4)$ & $1312(50.7)$ & $47(77.0)$ & $1749(85.8)$ \\
\hline Part time work & $15(9.9)$ & $498(10.8)$ & $13(14.4)$ & $408(15.8)$ & $2(3.3)$ & $14(0.7)$ \\
\hline Working w/Welfare & $12(7.9)$ & $52(1.1)$ & $9(10.0)$ & $38(1.5)$ & $3(4.9)$ & $14(0.7)$ \\
\hline Non-employed & $37(24.5)$ & $1018(22)$ & $28(31.1)$ & $832(32.1)$ & $9(14.8)$ & $186(9.1)$ \\
\hline \multicolumn{7}{|l|}{ Household characteristics } \\
\hline Same spouse/partner as in 1987 & $45(29.8)$ & $1950(42.2)$ & $30(33.3)$ & $1083(41.8)$ & $15(24.6)$ & $867(42.5)$ \\
\hline Changed partner between 1987 and 1992 & $34(22.5)$ & $724(15.6)$ & $19(21.1)$ & $410(15.8)$ & $15(24.6)$ & $314(15.4)$ \\
\hline New couple-no partner in 1987 & $72(47.7)$ & $1955(42.2)$ & $41(45.6)$ & $1097(42.4)$ & $31(50.8)$ & $858(42.1)$ \\
\hline \multicolumn{7}{|l|}{ Sex } \\
\hline Male & $61(40.4)$ & $2039(44)$ & & & & \\
\hline Female & $90(59.6)$ & $2590(56)$ & & & & \\
\hline \multicolumn{7}{|l|}{ Ethnicity } \\
\hline White & $110(73)$ & $3766(81.4)$ & $66(73.4)$ & $2116(81.7)$ & $44(72.1)$ & $1650(80.9)$ \\
\hline African American & $29(19.2)$ & $500(10.8)$ & $13(14.4)$ & $270(10.4)$ & $16(26.2)$ & $230(11.3)$ \\
\hline Others & $12(7.9)$ & $363(7.8)$ & $11(12.2)$ & $204(7.9)$ & $1(1.6)$ & $159(7.8)$ \\
\hline Having a health condition limiting work for pay & $5(3.3)$ & $155(3.3)$ & $3(3.3)$ & $99(3.8)$ & $2(3.3)$ & $56(2.7)$ \\
\hline In 1987, arguments become physical & $24(15.6)$ & $192(4.1)$ & $16(17.8)$ & $117(4.5)$ & $8(13.1)$ & $75(3.7)$ \\
\hline In 1987, respondent had alcohol problems & $\begin{array}{l}7(5) \\
\text { Mean (SD) }\end{array}$ & $\begin{array}{l}76(1.6) \\
\text { Mean }(S D)\end{array}$ & $1(1.1)$ & $22(0.8)$ & $6(9.8)$ & $54(2.6)$ \\
\hline Years of education in 1992 & $12.5(2.6)$ & $13.4(2.8)$ & $12.3(2.5)$ & $13.2(2.7)$ & $12.7(2.7)$ & $13.7(2.9)$ \\
\hline Years of age in 1992 & $33.4(6.7)$ & $40.3(10.2)$ & $33(7.0)$ & $39.8(10.1)$ & $34.1(6.3)$ & $40.9(10.3)$ \\
\hline Weeks unemployed and looking for work in 1991 & $3.5(9.3)$ & $1.4(6.2)$ & $4.2(10.3)$ & $1.4(6.4)$ & $2.4(7.5)$ & $1.4(6.0)$ \\
\hline Total number of children in household in 1992 & $1.9(1.3)$ & $1.5(1.3)$ & $1.9(1.1)$ & $1.5(1.4)$ & $1.9(1.6)$ & $1.4(1.3)$ \\
\hline Total family income, 1992 & $\begin{array}{l}\$ 43918 \\
\quad(44438)\end{array}$ & $\begin{array}{l}\$ 56723 \\
\quad(51423)\end{array}$ & $\begin{array}{l}\$ 42035 \\
\quad(48233)\end{array}$ & $\begin{array}{l}\$ 56252 \\
\quad(56825)\end{array}$ & $\begin{array}{l}\$ 46696 \\
\quad(38379)\end{array}$ & $\begin{array}{l}\$ 57321 \\
\quad(43614)\end{array}$ \\
\hline Number of alcohol drinks in past 30 days & $21.8(37)$ & $11.2(25.3)$ & $12.8(31.2)$ & $6.3(15.1)$ & $35(40.9)$ & $17.3(33.1)$ \\
\hline Index of satisfaction with social relationships & $10.1(2.2)$ & $11.5(2.1)$ & $9.9(2.2)$ & $11.6(2.1)$ & $10.5(2.3)$ & $11.4(2.1)$ \\
\hline
\end{tabular}

respondents report more violent arguments than white respondents or those categorised as others.

Because of sample size considerations we were not able to analyse men and women separately. Table 1 includes a description of the

Table 2 Multiple logistic regression model of association between family violence and employment status, adjusted for sociodemographic differences (long model)

\begin{tabular}{|c|c|c|c|}
\hline \multirow[b]{2}{*}{ Factor } & \multirow[b]{2}{*}{ Odds ratio } & \multicolumn{2}{|c|}{$95 \%$ Confidence intervals } \\
\hline & & Lower & Upper \\
\hline \multicolumn{4}{|l|}{ Employment status in 1992} \\
\hline Full time work & 1.00 & - & - \\
\hline Part time work & 1.019 & 0.495 & 1.942 \\
\hline Working w/Welfare & 3.338 & 1.104 & 9.029 \\
\hline Non-employed & 0.993 & 0.588 & 1.644 \\
\hline \multicolumn{4}{|l|}{ Employment history } \\
\hline $\begin{array}{l}\text { In past year number of weeks unemp/look work } \\
\text { Household characteristics }\end{array}$ & 1.014 & 0.99 & 1.034 \\
\hline Changed partner between 87 and 92 & 0.893 & 0.499 & 1.584 \\
\hline No partner in 87 (new couples) & 1.293 & 0.843 & 1.997 \\
\hline Total household income in $1992^{\star}$ & 0.792 & 0.582 & 1.081 \\
\hline Total number of children in household in 92 & 1.222 & 1.057 & 1.403 \\
\hline Age & 0.935 & 0.911 & 0.957 \\
\hline \multicolumn{4}{|l|}{$\operatorname{Sex}$} \\
\hline male & 1.00 & - & - \\
\hline female & 1.398 & 0.917 & 2.129 \\
\hline Years of education in 92 & 0.93 & 0.856 & 1.009 \\
\hline Satisfaction with social relationship & 0.767 & 0.713 & 0.825 \\
\hline Total number of drinks in past 30 days & 1.425 & 1.278 & 1.593 \\
\hline \multicolumn{4}{|l|}{ Ethnicity } \\
\hline White & 1 & - & - \\
\hline African American & 1.637 & 0.884 & 2.882 \\
\hline Others & 0.84 & 0.375 & 1.687 \\
\hline \multicolumn{4}{|l|}{ Physical condition } \\
\hline \multicolumn{4}{|l|}{ Any health condition limiting working for pay? } \\
\hline No & 1 & - & - \\
\hline Yes & 1.008 & 0.343 & 2.487 \\
\hline \multicolumn{4}{|l|}{1987 variables } \\
\hline \multicolumn{4}{|l|}{ In 1987 did arguments became physical? } \\
\hline No & 1.00 & - & - \\
\hline Yes & 5.514 & 3.048 & 9.711 \\
\hline \multicolumn{4}{|l|}{ Did respondent had alcohol problems in $1987 ?$} \\
\hline 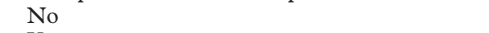 & 1.00 & - & - \\
\hline Yes & 1.394 & 0.5 & 3.361 \\
\hline
\end{tabular}

${ }^{\star}$ Income in thousands of dollars ${ }^{\star \star} 0.25 .+\log ($ alcohol number +0.5$)$. In all our analyses the data were weighted to control for the over-sampling procedure and to replicate the US distribution using the weights prepared by the NSFH researchers. For details see: Sweet JA, Bumpass LL, Call VRA. ${ }^{41}$ sample by gender group, and the possible implications of not analysing them separately are considered in the discussion section.

Table 2 presents the results of our first logistic regression analyses using the full model described in figure 1. Significant predictors for violent arguments include number of children in the household, alcohol drinking in 1992, and previous (1987) history of engaging in violent arguments. The risk of violence was greater for people who were working while receiving welfare relative to the referent (full time employed).

Two factors significantly reduce the likelihood of engaging in violent arguments: age and satisfaction with relationships with family (other than spouse) and friends. Higher income and education are also associated with less likelihood of reporting violence, but the confidence intervals are relatively wide.

Men and women are not significantly different in reporting having arguments in which both partners were physically violent. Other factors that are not statistically significant in predicting violence include race/ethnicity, partnership stability, having a physical or mental limitation that could restrict the ability of working for pay, the numbers of week of unemployment while looking for work in 1991, and previous (1987) history of having alcohol problems.

Table 3 presents the results of our reduced model where we dropped variables that did not attain significance in the full model, and three separate models that include reduced model variables and interaction effects for employment status and satisfaction with relationships or alcohol misuse or number of children. In our reduced model we find that people working while receiving welfare are almost four times more likely to report violence than other work- 
Table 3 Reduced model, and interactions. Multiple logistic regression model of association between family violence and employment status

\begin{tabular}{|c|c|c|c|c|c|c|c|c|c|c|c|c|}
\hline \multirow[b]{3}{*}{ Factors } & \multicolumn{3}{|c|}{ Reduced model } & \multicolumn{3}{|c|}{$\begin{array}{l}\text { Model with interactions: } \\
\text { employment and } \\
\text { satisfaction with social } \\
\text { relationships }\end{array}$} & \multicolumn{3}{|c|}{$\begin{array}{l}\text { Model with interactions: } \\
\text { employment and alcohol }\end{array}$} & \multicolumn{3}{|c|}{$\begin{array}{l}\text { Model with interactions: } \\
\text { employment and number } \\
\text { of children }\end{array}$} \\
\hline & \multirow{2}{*}{$\begin{array}{l}\text { Odds } \\
\text { ratio }\end{array}$} & \multicolumn{2}{|c|}{$95 \% C I$} & \multirow{2}{*}{$\begin{array}{l}\text { Odds } \\
\text { ratio }\end{array}$} & \multicolumn{2}{|c|}{$95 \% C I$} & \multirow{2}{*}{$\begin{array}{l}\text { Odds } \\
\text { ratio }\end{array}$} & \multicolumn{2}{|c|}{$95 \% C I$} & \multirow{2}{*}{$\begin{array}{l}\text { Odds } \\
\text { ratio }\end{array}$} & \multicolumn{2}{|c|}{$95 \% C I$} \\
\hline & & Lower & Upper & & Lower & Upper & & Lower & Upper & & Lower & Upper \\
\hline \multicolumn{13}{|l|}{ Employment status 1992} \\
\hline Full time work & 1.00 & - & - & 1.00 & - & - & 1.00 & - & - & 1.00 & - & - \\
\hline Part time work & 1.05 & 0.51 & 1.99 & 5.30 & 0.39 & 54.84 & 1.09 & 0.44 & 2.38 & 1.13 & 0.37 & 3.14 \\
\hline Working w/Welfare & 3.70 & 1.27 & 9.73 & 1.79 & 0.03 & 95.80 & 3.57 & 0.82 & 12.01 & 2.91 & 0.21 & 22.89 \\
\hline Non-employed & 1.01 & 0.60 & 1.65 & 2.54 & 0.44 & 14.11 & 0.52 & 0.24 & 1.05 & 2.26 & 1.06 & 4.72 \\
\hline Total number of children in household in 92 & 1.23 & 1.07 & 1.41 & 1.25 & 1.08 & 1.43 & 1.25 & 1.08 & 1.43 & 1.39 & 1.17 & 1.64 \\
\hline Satisfaction with social relationship & 0.77 & 0.71 & 0.82 & 0.80 & 0.73 & 0.87 & 0.77 & 0.71 & 0.83 & 0.77 & 0.71 & 0.82 \\
\hline Total number of drinks in past 30 days & 1.42 & 1.28 & 1.59 & 1.43 & 1.28 & 1.60 & 1.31 & 1.15 & 1.50 & 1.41 & 1.27 & 1.58 \\
\hline \multicolumn{13}{|l|}{ In 1987 did arguments became physical? } \\
\hline No & 1.00 & - & - & 1.00 & - & - & 1.00 & - & - & 1.00 & - & - \\
\hline Yes & 5.94 & 3.31 & 10.37 & 5.79 & 3.21 & 10.16 & 5.97 & 3.33 & 10.44 & 5.88 & 3.27 & 10.28 \\
\hline \multicolumn{13}{|l|}{ Interactions } \\
\hline Full time work/satisfaction with relationships & & & & 1.00 & - & - & & & & & & \\
\hline Part time work/satisfaction with relationships & & & & 0.85 & 0.67 & 1.09 & & & & & & \\
\hline Working with welfare/satisfaction with relationships & & & & 1.07 & 0.75 & 1.54 & & & & & & \\
\hline Non-employed/satisfaction with relationships & & & & 0.91 & 0.77 & 1.08 & & & & & & \\
\hline Full time work/alcohol drinks & & & & & & & 1.00 & - & - & & & \\
\hline Part time work/alcohol drinks & & & & & & & 0.92 & 0.61 & 1.36 & & & \\
\hline Working with welfare/alcohol drinks & & & & & & & 0.98 & 0.58 & 1.70 & & & \\
\hline Non-employed/alcohol drinks & & & & & & & 1.41 & 1.11 & 1.82 & & & \\
\hline Full time work/number of children & & & & & & & & & & 1.00 & - & - \\
\hline Part time work/number of children & & & & & & & & & & 0.94 & 0.59 & 1.41 \\
\hline Working with welfare/number of children & & & & & & & & & & 1.03 & 0.51 & 2.28 \\
\hline Non-employed/number of children & & & & & & & & & & 0.64 & 0.45 & 0.88 \\
\hline
\end{tabular}

The model controls for age, sex, income and education.

ing respondents. Number of alcohol drinks, and number of children in the family are again significant risk factors for violent arguments, and satisfaction with social relationships significantly protects against violence.

Columns 2 to 4 of table 3 summarise our analyses that include interaction effects. We run interactions of employment status with the other three factors significantly associated with violence and of theoretical interest to ussatisfaction with relationships, alcohol drinks and number of children in the family in separate, parallel models. Relative to full time workers a higher number of children significantly increases the risk of violence for the non-employed. Relative to full time workers more alcohol drinks slightly increases the risk of violence for the non-employed. Numbers of children and alcohol drinks does not significantly increase the risk of violence for those working while receiving welfare relative to full time workers. Satisfaction with relationships does not significantly interact with employment status to predict violence. We do not include a model with all main and interaction effects because of cell size considerations. Thus we cannot simultaneously compare the modifying effects of alcohol drinks, satisfaction with relationships and number of children on the relationship between employment status and violence.

\section{Discussion}

In this study we focus on arguments in which both partners engage in physical violence, which represent about $60 \%$ of cases of family violence in the NSFH. People who are only recipients of violence by their partners may have different characteristics than those who react violently, and should be studied sepa- rately. In addition, it should be noted that our sample included respondents who were in a stable relationship between 1987 and 1992, and those who were in a new or different relationship in 1992. Respondents that were not in a relationship in 1992 could not be included in the analysis. Generalisations to the whole US population should be made cautiously.

The greatest strength of this study is that it is based on a national probability sample thereby reducing sample selection bias and includes a rich set of important variables to permit examination of potential confounders. Our study presents a number of important findings. In contrast with popular perception we find that race/ethnicity is not a significant factor in predicting violent arguments when other factors are accounted for. Partnership instability has not been controlled for in previous studies of alcohol and family violence; however, we find partnership instability to not be a risk factor for violence, after controlling for other factors.

As previously reported in the literature, alcohol use is positively associated with violent arguments in the same year. Alcohol use five years earlier seems not to affect current violence. Prior research has not clarified the modifying effect of alcohol misuse on the relation between unemployment and violence. We do find that alcohol interacts with nonemployment to predict violence; alcohol use, moreover, does not increase the risk of violence among other employed groups in relation to the full time employed. It should be noted that we used a measure of alcohol intake widely used in the alcohol research literature (that is, number of drinks in the past 30 days).$^{42}$ Many of our other variables of interest report events in the past 6 or 12 months, which may possibly limit the usefulness of the alcohol variable. We 
were constrained in our choice of this variable because the NSFH does not provide information on whether the alcohol drinking pattern of respondents was any different during the rest of the year.

This study has certain limitations. Our exclusion criteria, and the factors we control for in our model, should eliminate most of the differences among the various groups of people included in our model, but uncontrolled variables determining both resources and outcomes may still exist. People who have antisocial personality characteristics are also likely to drink in large amounts ${ }^{43-45}$; making causal interpretations difficult because of potential confounding of characteristics of people most likely to be violent with the circumstances under which they drink and become violent. Neither personality characteristics nor circumstances can explain alcohol related violence without consideration of the purposes served by drinking and the properties of alcohol in relation to violence. ${ }^{46}$ Personality characteristics are not included as variables in our study, but we control for previous history of both violence and alcohol problems. Those who reported violent arguments in 1987 are almost six times more likely to report violence in 1992.

Under-reporting is an additional limitation of most studies of family violence because it is a sensitive issue about which people may be hesitant to speak openly. The possible reasons for under-reporting in the NSFH data have been previously discussed..$^{39}$ The NSFH placed the violence questions in the middle of a lengthy interview, and kept the questions general rather than specific. In addition, the questions referred to violence only in the context of disagreements, while violent abuse could occur without being prompted by a disagreement, and sexual violence was not included in the definition. When we analysed the small number of missing responses to the violence questions we did not find evidence of differences between respondents and nonrespondents regarding, age, sex or marital status.

Sample size considerations did not allow us to run models separately for men and women taking into account who was the perpetrator of the violence. In future research it would be useful to study men and women separately to better understand the possible relation between women employment patterns, age of children in the household, and other determinants that could influence the permanence of women in violent relationships. In future studies it would also be useful to include additional information on partners' characteristics. Larger sample sizes, new methods of diminishing underreporting, and/or different methodological approaches will be necessary to build on this line of research.

In conclusion, perhaps the most important findings of this study are the increased risk of violence if working and receiving welfare and the inhibiting effect of satisfaction with social relationships on violence. In view of recent welfare reform strategies our findings are particularly relevant. Our results indicate that, relative to the employed, people working while receiving welfare could be at greater risk for violence.

One plausible explanation for the increased risk for respondents receiving welfare while working is that the additional stress associated with working in low skills jobs when coping with poverty and child care issues puts people at a higher risk of family violence. Recent research shows that working couples with small children tend to work more hours than others, and they report the lowest quality of life among working couples ( $\mathrm{P}$ Moen et al, Annual Meeting of the American Association of Science, Anaheim, California, January 1999). However, we find that more children slightly increases the risk of violence only for the unemployed relative to full time workers. This suggests that job conditions, for example, low skill or less secure; personality characteristics; stigma related to receiving welfare; or some other unmeasured characteristic may explain this very intriguing result.

At any rate, this study suggests we should continue to take a comprehensive approach to problems of domestic violence. We have identified a group who is particularly at risk for family violence, which makes it critical to monitor the impact of welfare reform on family violence.

The data were generously provided by the Center for Demography and Ecology at the University of Wisconsin-Madison. The survey was designed and carried out at the Center for Demography and Ecology at the University of Wisconsin-Madison under the direction of Larry Bumpass and James Sweet. Field work was done by the Institute for Survey Research at Temple University. A previous version of this paper was presented at the North Miami, Florida, January 1998.

Funding: we would like to thank Cornell Agricultural Experiment Station for the award of a Hatch Grant that made possible this research effort. The National Survey of Families and Households (NSFH) was funded by a grant (HD21009) from the Center for Population Research of the National Institute of Child Health and Human Development.

Conflicts of interest: none.

1 US Department of Health and Human Services Public Health Service. Healthy People 2000: National health promotion and disease prevention objectives. Washington DC: Government Printing Office, 1991

2 Cambell JC, Lewandowski LA. Mental and physical health effects of intimate partner violence on women and children. Psychiat Clin North Am 1997;20:353-74

3 Straus MA, Gelles RJ. 1990. How violent are American Families? Estimates from the National Family Violence Resurvey and other studies. In: Straus MA, Gelles RJ, eds. Physical violence in American families: risk factors and adaptations to violence in 8,145 Families. New Brunswick, NJ: Transaction Publishers, 1990:95-112.

4 Federal Bureau of Investigation. 1994. Uniform Crime Reports (UCR): Crime in the US. Washington, DC: Government Printing Office, 1993.

5 Straus MA, Gelles RJ, Steinmetz SK. Behind closed doors: violence in the American family. New York: Anchor Books, violen 1981.

6 Brush L. Violent acts and injurious outcomes in married couples: new data from the National Survey of Families and Household. National Survey of Families and Households Working Paper no 6. Madison: University of WisconsinMadison, 1989

7 Dobash RE, Dobash RP. Violence against wives: a case against the patriarchy. New York: Free Press, 1979.

8 Johnson MP. Patriarchal terrorism and common couple violence: two forms of violence against women. Fournal of Marriage and Family 1995;57:283-94.

9 Yllo K. Political and methodological debates in wife abuse research. In: Yllo K, Bogard M, eds. Feminist perspectives on wife abuse. Newbury Park, CA: Sage, 1988:28-50.

10 Gelles RJ, Straus MA. Intimate violence: the causes and consequences of abuse in the American family. New York: Simon quences of abuse in the.

11 Gelles RJ, Loseke DR. Current controversies on family violence. Newbury Park, CA: Sage Publications, 1993. 
12 Anderson KL. Gender, status, and domestic violence: an integration of feminist and family violence approaches. integration of feminist and family violence app
fournal of Marriage and Family. 1997;59:655-69.

13 Lin RL, Shah CP, Svoboda TJ. The impact of unemployment on health: a review of the evidence. F Public Health Policy 1997;18:275-300

14 Roizen J. Issues in the epidemiology of alcohol and violence. Alcohol and Interpersonal Violence 1993;1:3-35.

15 Pernanen K. Alcohol in human violence. New York: Guilford Press, 1991.

16 Yegidis BL. Family violence: contemporary research findings and practice issues. Community Ment Health $\mathcal{F}$

17 Gortner ET, Gollan JK, Jacobson NS. Psychological aspects of perpetrators of domestic violence and their relationships

with the vic review of the research on men who batter. In: Galanter M, review of the research on men who batter
ed. Recent Dev Alcohol 1997;13:337-56.

19 Pernanen K. Alcohol-related violence: conceptual models and methodological issues. In: Martin SE, ed. Alcohol and Interpersonal Violence. Rockville, MD: US Department of Health and Human Services, 1993:37-69.

20 Kenkel DS, Ribar DC. Alcohol consumption and young adults' socioeconomic status. Brooking Pap Eco Ac 1994;1: 119-75.

21 US Department of Health and Human Services. Ninth Special Report to the US Congress on Alcohol and Health Rockville MD: The Secretary of Health and Human Services, 1997.

22 Heyman RE, O'Leary KD, Jouriles EN. Alcohol and aggressive personality styles: Potentiators of serious physical aggression against wives. Fournal of Family Psychology 1995;9:44-57.

23 D'Arcy C. Unemployment and health: data and implications. Can $\mathcal{F}$ Public Health 1986;77:124-31.

24 Vinokur AD, Price RH, Caplan RD. Hard times and hurtful partners: how financial strain affects depression and partners: how financial strain affects depression and
relationship satisfaction of unemployed persons and their relationship satisfaction of unemployed perso
spouses. F Pers Soc Psychol 1996;71:166-79.

25 Catalano R, Novaco R, McConnell. A model of the net effect of job loss on violence. $\mathcal{F}$ Pers SocPsychol 1997;72. effect of

26 Barling J, Rosenbaum A. Work stressors and wife abuse. $\mathcal{F}$ Applied Psychol 1986;71:346-8.

27 Kornblit AL. Domestic violence-an emerging health Issue. Soc Sci Med 1994;39:1181-8.

28 Mishel L, Bernstein J, Schmitt J. The state of working America 1996-97. Economic Policy Institute Series. New York: Armonk: M E Sharpe, 1997

29 Rodriguez, E. Social benefits and the life-cycle: understanding the predictors of part-time versus full-time employment. Research in Sociology of Work 2000;8:165-85.
30 Meyer B, Rosenbaum D. Welfare, the Earned Income Tax Credit and the labor supply of single mothers. Northwestern, L: Nothwestern University, Joint Center for Poverty Research, 1998.

31 Bishop JH. Is welfare reform succeeding? Working paper number 98-15. Ithaca, NY: Cornell University, Center for Advanced Human Resources Studies, 1998.

32 Chavkin W, Wise PH, Elman D. Topics for our times: welfare reform and women's health. Am f Public Health 1998;88:1017-18.

33 Aldwin CM. Stress, coping, and development: an integrated prospective. New York: The Guilford Press, 1995.

34 McKenry PC, Julian TW, Gavazzi SM. Toward a biopsychosocial model of domestic violence. fournal of Marriage and Family. 1995;57:307-20.

35 Menaghan EG. Work experiences and family interaction processes: the long reach of the job? Annual Review of Sociology 1991;17:419-44.

36 Weed DL. Beyond black box epidemiology. Am f Public Health 1998;88:12-14.

37 Levine FJ, Rosich KJ. Social causes of violence: crafting a science agenda. Washington, DC: American Sociological Association, 1996

38 Wallace D, Wallace R. Scales of geography, time, and population: the study of violence as a public health problem. Am F Public Health 1998;88:1853-8.

39 Brush LD. Violent acts and injurious outcomes in married couples: methodological issues in the National Survey of Families and Households. Gender and Society 1990;4:5667.

40 SAS/STAT. User's guide. Version 6, 4th ed. Cary, NC: SAS Institute, 1996.

41 Sweet JA. Bumpass LL, Call VRA. National Survey of Families and Households, 1987-1994. Madison. WI: Center for Demography and Ecology. University of WisconsinMadison, 1999

42 Caetano R. The epidemiology of alcohol-related problems in the US: concepts, patterns and opportunities for research. Drugs and Society 1997;11:43-71.

43 Gelles RJ, Cornell CP. International perspectives on family violence. Lexington: Lexington Books, 1983.

44 Leonard KE, Bromet EJ, Parkinson DK, et al. Patterns of alcohol use and physically aggressive behavior in men. 7 Stud Alcohol 1985;46:279-82.

45 McKenna T, Pickens R. Alcoholic children of alcoholics. $\mathcal{F}$ Stud Alcohol 1981;42:1021-9.

$46 \mathrm{McCord}$ J. Considerations of causes in alcohol-related violence. In: Martin SE, ed. Alcohol and interpersonal violence: fostering multidisciplinary perspectives. Rockville, MD: US Department of Health and Human Services, 1993:71-9. 